\title{
SYMBOLS AND ABBREVIATIONS
}

\section{Repository Symbols}

The original locations of documents that appear in the text are described by symbols. The guide used for American repositories has been Symbols of American Libraries, 11 th ed. (Washington, D.C.: Library of Congress, 1976). Foreign repositories and collections have been assigned symbols that conform to the institutions' own usage. In some cases, however, it has been necessary to irmulate acronyms. Acronyms have been created for private manuscript collections as well.

\section{Repositories}

Af. Archives africaines, Brussels, Belgium

AI)SL Archives of the Department of State, Ministry of Foreign Affairs, Monrovia, Liberia

AF RC Federal Archives and Records Center, East Point, Georgia

AMAE Archives du Ministère des affaires étrangères, Paris

AMNE Arquivo do Ministério dos negócios estrangeiros, Lisbon

ANISOM Archives nationales, Section d'outre-mer, Paris

As

Archives du Sénégal, Dakar

As MAE Archivio storico del Ministero degli affari esteri, Rome

A7T Tuskegee Archives, Tuskegee Institute, Alabama

A7Ta Talladega College Historical Archives, Talladega, Alabama

BM British Museum Archives, London

CAOM Centre des archives d'outre-mer, Aix-en-Provence, France

CAA University of Cape Town Library, Cape Town, South Africa

D.AB Department of Archives, Black Rock, Barbados

D]ßFAP Archives of the Département évangélique français d'action apostolique, Paris

D)-FBI Federal Bureau of Investigation, United States Department of Justice, Washington, D.C. 
The Marcus Garvey aNd UNIA Papers

DLC Library of Congress, Washington, D.C.

DNA National Archives, Washington, D.C.

$\begin{array}{ll}\text { RG } 59 & \begin{array}{l}\text { General Records of the Department of State } \\ \text { General Records of the Department of Jus- } \\ \text { tice } \\ \text { Records of the Federal Bureau of Investi- } \\ \text { gation }\end{array} \\ \text { RG } 65 & \begin{array}{l}\text { Records of Foreign Service Posts of the } \\ \text { Department of State }\end{array} \\ \text { RG } 84 & \begin{array}{l}\text { Records of the Adjutant Gencral's Office, } \\ \text { l780s-1917 }\end{array} \\ \text { RG 165 } & \begin{array}{l}\text { Records of the War Department, General } \\ \text { and Special Staffs, Military Intelligence } \\ \text { Division }\end{array} \\ \text { RG 204 } & \begin{array}{l}\text { Records of the Office of the Pardon Attor- } \\ \text { ney }\end{array} \\ \text { RG 233 } & \begin{array}{l}\text { Records of the United States House of } \\ \text { Representatives }\end{array}\end{array}$

GAPT Pitts Theology Library, Emory University, Atlanta, Georgia

GPRO Gambia Public Records Office, Banjul

IU University of Ibadan Library, Ibadan, Nigeria

JA Jamaica Archives, Spanish Town, Jamaica

KCAL Killie Campbell Africana Library, University of Natal, Durban, South Africa

KNA Kenya National Archives, Nairobi

LNA League of Nations Archives, Geneva

MMS Methodist Missionary Society, London

$\mathrm{MsHaU} \quad$ University of Southern Mississippi, Hattiesburg

MU

University of Massachusetts Library, Amherst

$\mathrm{NaGh}$ National Archives of Ghana, Accra (Regional Office, Cape Coast)

NAL National Archives of Lesotho, Maseru

NaMal National Archives of Malawi, Zomba

NAN National Archives of Nigeria, Ibadan

NAN-E National Archives of Nigeria, Enugu Branch 
SYMBOLS AND ABRREVIATIONS

NaNam National Archives of Namibia, Windhoek

$\mathrm{NaTan} \quad$ National Archives of Tanzania, Dar cs Salaam

NaZam National Archives of Zambia, Lusaka

NaZim National Archives of Zimbabwe, Harare

NNJ-Sc Schomburg Center for Research in Black Culture, New York Public Library, New York

NIJHR New York Supreme Court, Hall of Records, New York

Or State Library, Salem, Oregon

PAOSL Sierra Leone Public Archives Office, Fourah Bay College, Freetown

PRO Public Records Office, Kew, Surrey, England

$\mathrm{CAB} \quad$ British Cabinet Records

$\mathrm{CO} \quad$ Colonial Office

FO Foreign Office

WO War Office

SAGA South African Government Archives, Pretoria

SAGA-CA Cape Archives, Cape Town, South Africa

GSC Archives of the Registrar, Eastern Cape Division of the Supreme Court of South Africa

1/ELN Archives of the Magistrate, East London

1/MCR Archives of the Magistrate and Bantu Affairs Commissioner, Maclear

1/SPT Archives of the Magistrate and Bantu Affairs Commissioner, Sterkspruit (Herschel)

SAMAE Service des archives du Ministère des affaires étrangères, Brussels

SOAS School of Oriental and African Studies Library, University of London

TNF Fisk University, Nashville, Tennessee

UC:LA University of California, Los Angeles, Department of Special Collections

VEM Vereinigte Evangelische Mission, Wuppertal, Germany

ViHaI Hampton Institute, Hampton, Virginia 
The Marcus Garvey and UNLA Papers

WNRC Washington National Records Center, Suitland, Maryland RG 204 Records of the Pardon Attorney

WRHS Western Reserve Historical Society, Cleveland, Ohio

\section{Manuscript Collection Symbols}

AAG Amy Ashwood Garvey Papers, Lionel Yard Collection, Brooklyn, New York

AAS Arthur Schomburg Papers, NN-Sc

ADM Admiralty and Secretariat Papers, NaNam

AJG Amy Jacques Garvey Papers, TNF

AOC African Orthodox Church Papers, GAPT

AP

Atlanta Federal Penitentiary Records, AFRC

CGW Carter G. Woodson Collection, DLC

CJ Charles S. Johnson Papers, TNF

CSE Chief Secretary, Enugu, NAN

CSO Colonial Secretary's Office, JA, NAN

DAPC Direction des affaires politiques et commerciales, AMAE

DGNP Direcção geral dos negociós políticos, AMNE

GKSP God's Kingdom Socicty Papers, Nigeria

HM Herbert Macaulay Papcrs, IU

IMC/CBMS International Missionary Council / Conference for British Missionary Societies, SOAS

JEB John E. Bruce Papers, NN-Sc

KS Kobina Sekyi Papers, NaGh

LF Lionel Forman Papers, CSA

MC Ministero delle colonie, ASMAE

NAACP Papers of the National Association for the Advancement of Colored People, DLC

NMB Nicholas Murray Butler Papers, NNC

NTS Archives of the Department of Native Affairs, SAGA

RB Ralph Bunche Papers, UCLA

RRM Robert Russa Moton Papers, ATT 
SLCITFOM Service de liaison avec les originaires des territoires de la France d'outre-mer, ANSOM

TG]3 Theodore Bilbo Papers, MsHaU, McL

UCD Universal Negro Improvement Association, Central Division Papers, NN-Sc

WEBDB W. E. B. Du Bois Papers, MU

\section{Descriptive Symbols}

The following symbols are used to describe the character of the original documents.

$\begin{array}{ll}\text { AD: } & \text { Autograph document signed } \\ \text { AL } & \text { Autograph letter } \\ \text { ALI } & \text { Autograph letter initialed } \\ \text { ALs } & \text { Autograph letter signed } \\ \text { ALT } & \text { Autograph letter transcript } \\ \text { AMS } & \text { Autograph manuscript } \\ \text { AN } & \text { Autograph note } \\ \text { AN: } & \text { Autograph note initialed } \\ \text { AT( } ; & \text { Autograph telegram message } \\ \text { AT( } \text { iS }^{5} & \text { Autograph telegram message signed } \\ \text { PD } & \text { Printed document } \\ \text { TD } & \text { Typed document } \\ \text { TD:; } & \text { Typed document signed } \\ \text { TD' } & \text { Typed document transcript } \\ \text { TG } & \text { Telegram } \\ \text { TL } & \text { Typed letter } \\ \text { TLI } & \text { Typed letter initialed } \\ \text { TL5 } & \text { Typed letter signed } \\ \text { TLT } & \text { Typed letter transcript } \\ \text { TN } & \text { Typed note } \\ \text { TN] } & \text { Typed note initialed } \\ & \end{array}$




$\begin{array}{ll}\text { TNS } & \text { Typed note signed } \\ \text { TTG } & \text { Typed telegram } \\ \text { TTGS } & \text { Typed telegram signed }\end{array}$

\section{Abbreviations of Published Works}

$A P$

ATOR

$A Y R$

$B A$

$B B O M$

$B C B$

$B D B C G$

$B F Q$

$B M$

$\mathrm{Bm}$

BMo

$B N$

BPSAEL

CBD

$C D$

CHA

$D A B$

L. H. Gann and Peter Duignan, eds. African Proconsuls: European Governors in Africa. New York: Free Press, 1978.

African Times and Orient Review

The African Yearly Register: Being an Illustrated National Biographical Dictionary (Who's Who) of Black Folks in Africa. 2d ed. Johannesburg: R. L. Esson and Co., 1932.

O Brado Africano

Biographie belge d'outre-mer

Biographie coloniale belge

Anthony H. M. Kirk-Greene. A Biographical Dictionary of the British Colonial Governor. Vol. 1, Africa. Stanford, Calif.: Hoover Institution Press, 1980.

Bartlett's Familiar Quotations

Black Man, monthly, Kingston and London

Blackman, weekly, Kingston

E. David Cronon. Black Moses: The Story of Marcus Garvey and the Universal Negro Improvement Association. 2d ed. Madison: University of Wisconsin Press, 1969.

Biographie nationale

Les Switzer and Donna Switzer. The Black Press in South Africa and Lesotho. Boston: G. K. Hall and Co., 1979.

Cambridge Biographical Dictionary

Chicago Defender

J. D. Fage and Roland Oliver, eds. The Cambridge History of Africa. 8 vols. Cambridge: Cambridge University Press, 1975-1986.

Dictionary of American Biography 
DAHB Mark R. Lipschutz and R. Kent Rasmussen. Dictionary of African Historical Biography. 2d ed. Berkeley, Los Angeles, London: University of California Press, 1986.

$D A N B \quad$ Dictionary of American Negro Biography

$D B^{F} \quad$ Dictionnaire de biographie française

DG Daily Gleaner

$D N B \quad$ Dictionary of National Biography

DOCOL Dominions Office and Colonial Office List

$D P C \quad J e a n$ Jolly. Dictionnaire des parlementaires français: Notices biographiques sur les ministres, sénateurs et députés francais de 1889 à 1940. Paris: Presses Universitaires de France, 1960-1977.

$D S A B \quad$ Dictionary of South African Biography

EA Encyclopaedia Africana

EB Encyclopaedia Britannica

EBi'S G. Wesley Johnson, Jr. The Emergence of Black Politics in Senegal: The Struggle for Power in the Four Communes, 1900-1920. Stanford, Calif.: Stanford University Press, 1971.

ESAl Eric Rosenthal, comp. and ed. Encyclopaedia of Southern Africa. 6th ed. London and New York: Frederick Warne, 1973.

EWH William L. Langer, comp. and ed. An Encyclopedia of World History. 5th ed., rev. and enl. Boston: Houghton Mifflin Co., 1972.

FPC $\quad$ Thomas Karis and Gwendolen M. Carter, eds. From Protest to Challenge: A Documentary History of African Politics in South Africa, 1882-1964 4 vols. Vol. 1, Sheridan Johns III, Protest and Hope, 1882-1934 Vol. 4, Gail M. Gerhart and Thomas Karis, Political Profiles, 1882-1964 Stanford, Calif.: Hoover Institution Press, 1972-1977.

$G D A D$ Joseph E. Harris, ed. Global Dimensions of the African Diaspora. Washington, D.C.: Howard University Press, 1982.

GHA General History of Africa. Vol. 7, A. Adu Boahen, ed., Africa under Colonial Domination, 1880-1935. Paris: UNESCO; London: Heinemann; Berkeley and Los Angeles: University of California Press, 1985.

HLA Susan H. Broadhead. Historical Dictionary of Angola. Metuchen, N.J.: Scarecrow Press, 1992. 
HDC Victor T. Le Vine and Roger P. Nye. Historical Dictionary of Cameroon. Metuchen, N.J.: Scarecrow Press, 1974.

HDCAR Pierre Kalck. Historical Dictionary of the Central African Republic. Methuen, N.J.: Scarecrow Press, 1992.

HDCh Samuel Decalo. Historical Dictionary of Chad. Metuchen, N.J.: Scarecrow Press, 1977.

HDD Samucl Decalo. Historical Dictionary of Dahomey (People's Republic of Benin). Metuchen, N.J.: Scarecrow Press, 1976.

HDE Chris Prouty and Eugene Rosenfeld. Historical Dictionary of Ethiopia. Metuchen, N.J.: Scarecrow Press, 1981.

HDEg Joan Wucher King. Historical Dictionary of Egypt. Metuchen, N.J.: Scarecrow Press, 1984.

HDG Daniel Miles McFarland. Historical Dictionary of Ghana. Metuchen, N.J.: Scarecrow Press, 1985.

$H D G a$ Harry A. Gailey. Historical Dictionary of the Gambia. Metuchen, N.J.: Scarecrow Press, 1975.

HDGab David E. Gardinier. Historical Dictionary of Gabon. Metuchen, N.J.: Scarecrow Press, 1981.

HDGu Thomas E. O'Toole. Historical Dictionary of Guinea (Republic of Guinea/Conakry). Metuchen, N.J.: Scarecrow Press, 1978.

HDIC Robert J. Mundt. Historical Dictionary of the Ivory Coast (Côte d'Ivoire). Metuchen, N.J.: Scarecrow Press, 1987.

HDL D. Elwood Dunn and Svend E. Holsoe. Historical Dictionary of Liberia. Metuchen, N.J.: Scarecrow Press, 1985.

HDLe Gordon MacKay Haliburton. Historical Dictionary of Lesotho. Metuchen, N.J.: Scarecrow Press, 1977.

HDM Cynthia A. Crosby. Historical Dictionary of Malawi. Metuchen, N.J.: Scarecrow Press, 1980.

HDMa Pascal James Imperato. Historical Dictionary of Mali. 2d cd. Metuchen, N.J.: Scarecrow Press, 1986.

HDMo William Spencer. Historical Dictionary of Morocco. Metuchen, N.J.: Scarecrow Press, 1980.

HDMoz Mario Joaquim Azevedo. Historical Dictionary of Mozambique. Metuchen, N.J.: Scarecrow Press, 1991.

HDN A. Oyewole. Historical Dictionary of Nigeria. Metuchen, N.J.: Scarecrow Press, 1987.

HDNi Samuel Decalo. Historical Dictionary of Niger. 2d ed. Metuchen, N.J.: Scarecrow Press, 1989. 
HL'RGBCV Richard Lobban. Historical Dictionary of the Republics of Guinea-Bissau and Cape Verde. Metuchen, N.J.: Scarecrow Press, 1979.

HIIRZ R. Kent Rasmussen. Historical Dictionary of Rhodesia/ Zimbabwe. Metuchen, N.J.: Scarecrow Press, 1979.

HIS Lucie Gallistel Colvin. Historical Dictionary of Senegal. Metuchen, N.J.: Scarecrow Press, 1981.

HLSA Christopher C. Saunders. Historical Dictionary of South Africa. Metuchen, N.J.: Scarecrow Press, 1983.

HLISL Cyril P. Foray. Historical Dictionary of Sierra Leone. Metuchen, N.J.: Scarecrow Press, 1977.

HISo Margaret Castagno. Historical Dictionary of Somalia. Metuchen, N.J.: Scarecrow Press, 1979.

HL'T Samuel Decalo. Historical Dictionary of Togo. 2d ed. Metuchen, N.J.: Scarecrow Press, 1987.

HLUV Daniel Miles McFarland. Historical Dictionary of Upper Volta (Haute Volta). Metuchen, N.J.: Scarecrow Press, 1978.

HIZ John Joseph Grotpeter. Historical Dictionary of Zambia. Metuchen, N.J.: Scarecrow Press, 1979.

HIZa F. Scott Bobb. Historical Dictionary of Zaire. Metuchen, N.J.: Scarecrow Press, 1988.

He:D Hommes et destins (Dictionnaire biographique d'outre-mer). 4 vols. Paris: Académie des sciences d'outre-mer, 1975-1981.

IJAHS International Journal of African Historical Studies

JAit Journal of African History

JA:: Journal of the African Society

JH.iN Journal of the Historical Society of Nigeria

JN.' Journal of Negro History

JS $K S \quad$ Journal of Southern African Studies

LWR Lagos Weekly Record

LO $L \quad$ Robert A. Hill and Barbara Bair, eds. Marcus Garvey: Life and Lessons. Berkeley, Los Angeles, London: University of California Press, 1987.

MC:P Marcus Garvey Papers

NW Negro World

NYB Negro Year Book 
$N Y T$

$O D Q$

$P A M$

PEO

PẼP

RANSA

RASWA

$S A D N B$

$S A L B$

SASWA

SESA

$S L W N$

$T N$

$U B$

$W A$

$W B D$

WNGD

$W W A$

$W W C A$

WWCR

$W W W$

$W W W A$
New York Times

Oxford Dictionary of Quotations, 4th ed.

Imanuel Geiss. The Pan-African Movement: A History of PanAfricanism in America, Europe and Africa. Translated by Ann Keep. New York: Africana Publishing, 1974.

Amy Jacques Garvey, ed. Philosophy and Opinions of Marcus Garvey. 2 vols. 1923, 1925. Reprint (2 vols. in 1). New York: Atheneum, 1992.

Robert I. Rotberg and Ali A. Mazrui, eds. Protest and Power in Black Africa. New York: Oxford University Press, 1970.

Peter Walshe. The Rise of African Nationalism in South Africa: The African National Congress, 1912-1952 Berkeley and Los Angeles: University of California Press, 1971.

\section{Report of the Administrator of South West Africa}

Eric Rosenthal, comp. Southern African Dictionary of National Biography. London: Frederick Warne, 1966.

\section{South African Labour Bulletin}

Report Presented by the Government of the Union of South Africa to the Council of the League of Nations concerning the Administration of South West Africa

Standard Encyclopedia of Southern Africa. Cape Town, 1972.

Sierra Leone Weekly News

Times of Nigeria

Umteteli wa Bantu

West Africa

Webster's Biographical Dictionary

Webster's New Geographical Dictionary

Who's Who in America

Who's Who in Colored America

Who's Who of the Colored Race

Who Was Who

Who Was Who in America 


\section{Other Symbols and Abbreviations}

Included are abbreviations that are used generally throughout annotations of the text. Standard abbreviations, such as those for titles and scholastic degrees, are omitted. Abbreviations that are specific to a single annotation appear in parentheses after the initial citation and are used thereafter in the rest of the ann'station.

$\begin{array}{ll}\text { AC L } & \text { African Communities League } \\ \text { ANIE } & \text { African Methodist Episcopal Church } \\ \text { ANIEZ } & \text { African Methodist Episcopal Zion Church } \\ \text { ANC } & \text { African National Congress } \\ \text { ACIC } & \text { African Orthodox Church } \\ \text { APU } & \text { African Progress Union } \\ \text { BSL } & \text { Black Star Line, Inc. } \\ \text { CIIRN } & \text { Comité de défense de la race nègre } \\ \text { ICU } & \text { Industrial and Commercial Workers Union } \\ \text { LA } & \text { Liga Africana } \\ \text { LI'RN } & \text { Ligue de défense de la race nègre } \\ \text { LC DRN } & \text { Ligue universelle pour la défense de la race noire } \\ \text { NF.ACP } & \text { National Association for the Advancement of Colored People } \\ \text { NC'BWA } & \text { National Congress of British West Africa } \\ \text { SANNC } & \text { South African Native National Congress } \\ \text { SP. IO } & \text { Society of Peoples of African Origin } \\ \text { UNJIA } & \text { Universal Negro Improvement Association }\end{array}$


